\title{
The use of pyrolysis mass spectrometry in the characterization of Rhizobium meliloti
}

\author{
R. Goodacre*, A. Hartmann†, J.E. Beringer $\ddagger$ \& R.C.W. Berkeley*§ \\ *Department of Pathology and Microbiology, Bristol University, The School of Medical \\ Sciences, University Walk, Bristol BS8 ITD, UK, †Lab. de Microbiology des Sols, Institut \\ National de la Recherche Agronomique, 17, rue Sully, B.P. 1540, 21034 Dijon CEDEX, \\ France and $\ddagger$ Department of Botany, Bristol University, School of Biological Sciences, \\ Woodland Road, Bristol BS8 IUG, UK
}

JRN/114: received 5 June 1991 and accepted 6 June 1991

\begin{abstract}
Goodacre, R., Hartmann, A., Beringer, J.E. \& Berkeley, R.C.W. 1991. The use of pyrolysis mass spectrometry in the characterization of Rhizobium meliloti. Letters in Applied Microbiology 13, 157-160.

The discrimination of Rhizobium meliloti by pyrolysis mass spectrometry and DNA studies was investigated. It was found that the separation of these strains by these two methods was similar. When different Curie-point temperatures, $358^{\circ} \mathrm{C}$ and $530^{\circ} \mathrm{C}$, were employed the results obtained were highly correlated, even though the data were not comparable.
\end{abstract}

The ability of pyrolysis mass spectrometry (PyMS) to discriminate between closely related bacteria is now well established. Shute et al. (1984) have shown that Py-MS can differentiate between Bacillus subtilis and Bacillus amyloliquefaciens which is a demanding test for Py-MS because the distinction has been difficult to make using conventional methods. Py-MS has also been used to discriminate four genotypically related strains of Escherichia coli $\mathrm{K}-12$; a parent strain, UB5201, and three derivatives, each containing one of the antibiotic resistance plasmids, pBR322, pACYC184 or R388 (Goodacre \& Berkeley 1990).

Another useful method for discriminating between strains is to use procedures which compare relatedness at the level of DNA sequence. This is done by isolating DNA, cutting it with restriction enzymes, separating the fragments by electrophoresis, and hybridizing them to labelled DNA corresponding to sequences within the chromosome or plasmids.

$\S$ Corresponding author.
This procedure was used by Hartmann (1989) to distinguish isolates of Rhizobium meliloti.

In this study we compare the abilities of Py-MS and DNA hybridization to provide information about the relatedness of the Rhizobium meliloti strains.

\section{Materials and Methods}

BACTERIAL STRAINS

Eight strains of Rhizobium meliloti were used in this study; 111, 115, 124, 151, 214, 231, 333 and 342. They were isolated from an uninoculated field in 1983 (Hartmann 1989). All were maintained on yeast mannitol agar slopes at $-4^{\circ} \mathrm{C}$.

\section{GROWTH MEDIA}

For Py-MS studies all strains were grown on nutrient agar (Lab M, batch number BN90317) for $4 \mathrm{~d}$ at $28^{\circ} \mathrm{C}$. Yeast mannitol agar was prepared as described by Beringer et al. (1984). 
SAMPLE PREPARATION

Each of the clusters was grown in duplicate and two samples were prepared from each, giving four replicates for each culture.

Clean $\mathrm{Ni}-\mathrm{Fe}$ foils (Horizon Instruments, Heathfield, Sussex) were inserted, with clean forceps, into a clean pyrolysis tube (Horizon Instruments) so that $6 \mathrm{~mm}$ was protruding from the mouth of the tube. Bacterial growth was picked up, avoiding the growth medium surface, using a disposable plastic loop and smeared on $5 \mathrm{~mm}$ of the protruding part of the foil to give a uniform surface coating. The sample was then vacuum desiccated and the foil pushed 10 $\mathrm{mm}$ into the tube using a clean stainless steel depth gauge, to locate the sample tube for pyrolysis. Viton O-rings (Horizon Instruments) were placed on the tubes.

\section{PYROLYSIS MASS SPECTROMETRY}

The samples were analysed using a Horizon Instruments PYMS-200X pyrolysis mass spectrometer. Curie-point pyrolysis was at $358^{\circ} \mathrm{C}$, $530^{\circ} \mathrm{C}$ or $770^{\circ} \mathrm{C}$ for $4 \mathrm{~s}$ in a vacuum. The temperature is determined by the ratio of the iron to nickel alloy of the foil (ratio $\mathrm{Fe}: \mathrm{Ni}$ ) $358^{\circ} \mathrm{C}$ $(0: 100)$ and $530^{\circ} \mathrm{C}(50: 50)$. The expansion chamber, valve and collimating tube interfacing the pyrolysis tube with the mass spectrometer were heated at $150^{\circ} \mathrm{C}$. Fragments produced were ionized by collision with a cross beam of low energy $(30 \mathrm{eV})$ electrons, and the ions were separated in a quadrupole mass spectrometer, which scanned the pyrolysate 160 times at $0.2 \mathrm{~s}$ intervals from initiation of pyrolysis. Integrated ion counts at unit mass intervals from 51-200 were recorded on floppy disk, together with pyrolysis sequence number and total ion count for each specimen (Aries et al. 1986).

\section{MATHEMATICAL ANALYSIS}

Raw data were processed on an OPUS PCV computer, running programs written in the GENSTAT statistical language. The methods have been described previously (MacFie \& Gutteridge 1982; Gutteridge et al. 1985). The first stage is data normalization to remove the effect of sample size difference, followed by principal component analysis (Gutteridge et al. 1979) to reduce data for canonical variates analysis (CVA) (MacFie et al. 1978), a form of discriminant analysis (Windig et al. 1983). In CVA plots the $95 \%$ tolerance region is constructed round each sample mean by the Chi-squared distribution on two degrees of freedom (Krzanowski 1988). CVA produces a generalized distance matrix which can be transformed to a percentage similarity matrix, using the Gower similarity coefficient $S_{G}$ (Gower 1971), to make these data amenable to average linkage cluster analysis and to allow the production of the dendrogram or a minimum spanning tree.

\section{DNA STUDIES}

DNA isolation, restriction, separation, and hybridization procedures were as described by Maniatis et al. (1982), with the exception of nonradioactive hybridizations which were done with a Boehringer kit (Boehringer Corp. Ltd., Bell Lane, Lewes, E. Sussex) using the procedure outlined by the manufacturer. DNA was probed with the following plasmids: pRWRm13 (Wheatcroft \& Watson 1987), which contains $0.9 \mathrm{~kb}$ of the internal part of the $R$. meliloti insertion sequence ISRm1; pRmR2 (Ruvkun et al. 1982), which contains a $3.9 \mathrm{~kb}$ segment DNA from $R$. meliloti carrying nifH and part of nifD; pGMI42R (Julliot \& Boistard 1979), which contains a $10 \mathrm{~kb}$ sequence of $R$. meliloti chromosomal DNA. Total, or plasmid DNA alone, was restricted with $E c o R 1$ and hybridized with the different probes (Hartmann 1989; Hartmann \& Amarger 1991).

\section{Results and Discussion}

The dendrogram produced following DNA studies is shown in Fig. 1a. This represents the relationship of the strains derived from DNA probing, using a single or combination of probes. Similarity percentages are $\mathrm{n}) t$ available. It can be seen (Fig. 1a) that two clusters of $R$. meliloti strains emerge. The first cluster comprises strains 115 and 214 and the second 111, 124, 151, 231 and 333. Rhizobium meliloti 342 falls outside both clusters.

A CVA plot and dendrogram of data from pyrolysis at $530^{\circ} \mathrm{C}$ are shown in Figs $1 \mathrm{~b}$ and 2. Three distinct groupings can be observed. Strains 115 and 214 form one cluster as seen in 


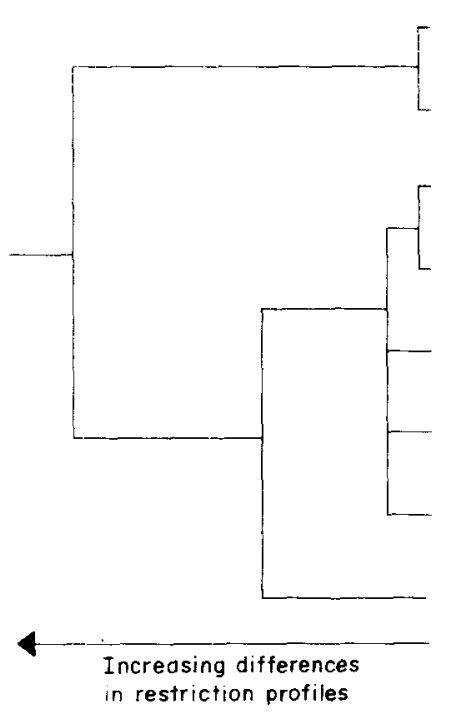

(a)

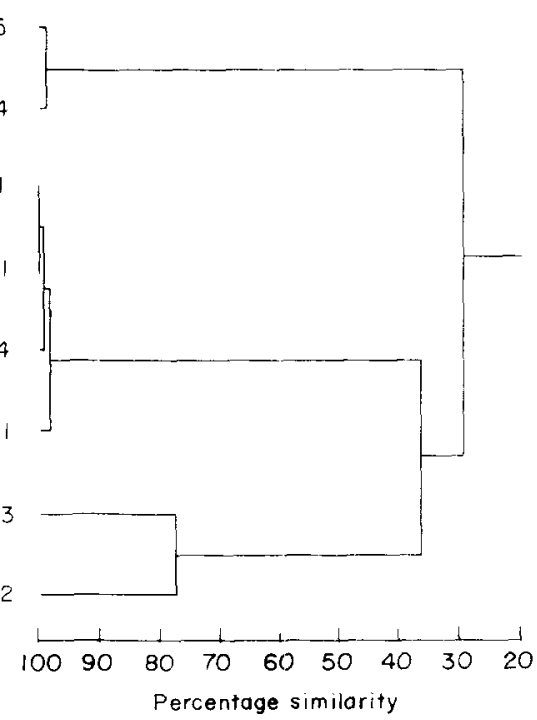

(b)

Fig. 1. Comparison of Rhizobium meliloti strains. Dendrogram produced by analysis of DNA studies showing the similarity of the same strains (from Hartmann 1989) (a). Dendrogram produced from Py-MS data showing the similarity of the $R$. meliloti strains grown on nutrient agar for $44 \mathrm{~d}$ (b).

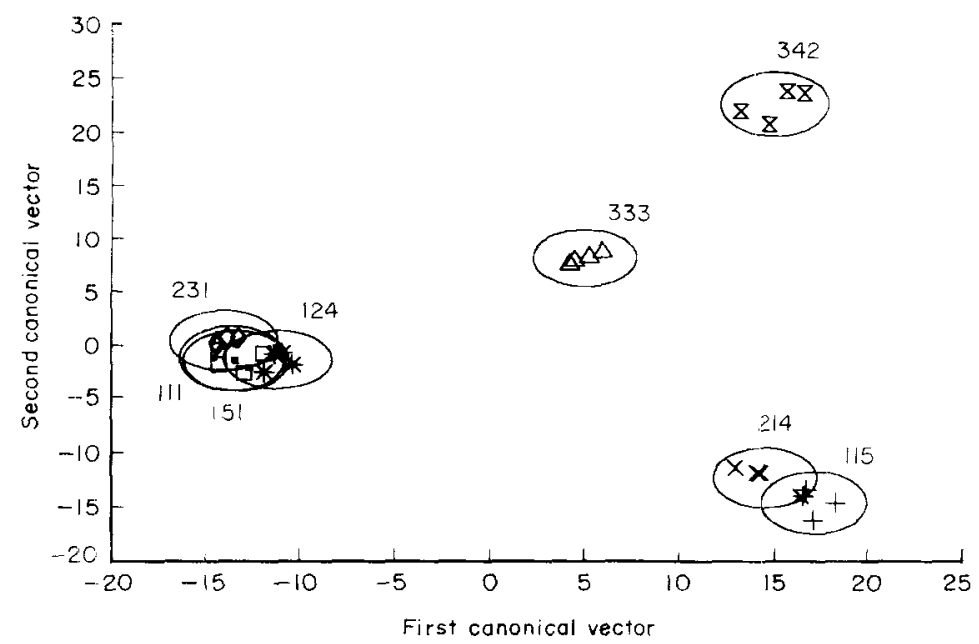

Fig. 2. Canonical variates plot produced by GENSTAT showing the similarity of the Rhizobium meliloti strains grown on nutrient agar for $4 \mathrm{~d}$.

Fig. 1a. The second cluster comprises $R$. meliloti $111,124,151$ and 231 ; these strains are all members of the second cluster derived from DNA studies. Finally strain 333 joins 342 at a lower similarity of $77.5 \%$, this is not mirrored in the dendrogram shown in Fig. 1a.

When the experiment was repeated using a pyrolysis temperature of $358^{\circ} \mathrm{C}$ an identical CVA plot and dendrogram was obtained (data not shown). It was not possible, however, to compare directly spectra with those obtained by pyrolysis at $530^{\circ} \mathrm{C}$. This is because at the different Curie-point temperatures thermolytic cleavage produced dissimilar pyrolysis fragments and hence visibly different spectra (not shown).

At first sight it may seem surprising that Py-MS and DNA procedures gave similar profiles of relatedness. DNA hydridization to 
restriction fragments should be totally independent of minor changes in metabolism or to the presence of additional plasmids, whereas both can be detected by pyrolysis (Goodacre \& Berkeley 1990; Goodacre et al. 1991). It has been previously seen, however, that analysis of strains by pyrolysis does correlate remarkably well with results obtained using classical and DNA hydridization methodology (O'Donnel et al. 1980). Clearly, Py-MS is more subject to changes in procedure, although Curie-point pyrolysis at temperatures of $358^{\circ} \mathrm{C}$ and $530^{\circ} \mathrm{C}$ gave highly correlated results, the data were not comparable.

In conclusion, the discrimination of these eight $\boldsymbol{R}$. meliloti strains by Py-MS successfully mirrors the separation of these strains based on DNA studies and demonstrates the potential for studies utilizing both procedures to provide information about the relatedness of populations of micro-organisms.

J.E.B. wishes to acknowledge financial support for part of this work from the EEC, under contracts BAP 0380-UK and CI1* 0545-UK. Financial support from SERC for R.G. is acknowledged.

\section{References}

Aries, R.E., Gutteridge, C.S. \& Ottley, T.W. 1986 Evaluation of a low cost, automated pyrolysis mass spectrometer. Journal of Analytical and Applied Pyrolysis 9, 81-98.

Beringer J.E., Ruiz Sainz, J.E. \& Johnston, A.W.B 1984 Methods for the genetic manipulation of Rhizobium. In Microbial Methods for Environmental Biotechnology, Society for Applied Bacteriology Technical Series, 19 eds. Grainger, J. M. \& Lynch, J.M. pp. 79-94. London: Academic Press.

GoODACRE, R. \& BERKeley, R.C.W. 1990 Detection of small genotypic changes in Escherichia coli by pyrolysis mass spectrometry. FEMS Microbiology Letters 71, 133-138.

Goodacre, R., Beringer, J.E. \& Berkeley, R.C.W. 1991 Detection of the fimbrial adhesive antigen F41 from Escherichia coli HB101 (pSLM204) by pyrolysis mass spectrometry. Journal of Analytical and Applied Pyrolysis (in press).

GowER, J.C. 1971 A general coefficient of similarity and some of its properties. Biometrics 27, 857-874.

Gutteridge, C.S., MaCFIE, H.J.H. \& NorRIS, J.R. 1979 Use of principal components analysis for displaying variation between pyrograms of microorganisms. Journal of Analytical and Applied Pyrolysis 1, 67-76.
GutTeridge, C.S., Vallis, L. \& MaCfie, H.J.H. 1985 Numerical methods in the classification of microorganisms by pyrolysis mass spectrometry. In Computer Assisted Bacterial Systematics ed. Goodfellow, M., Jones, D. \& Priest, F.G. pp. 369-401. London: Academic Press.

Julliot, J.S. \& BoisTARD, P. 1979 Use for RP4-prime plasmids constructed in vitro to promote a polarised transfer of the chromosome in Escherichia coli and Rhizobium meliloti. Molecular and General Genetics 73, 289-298.

Hartmann, A. 1989 Characterisation du genome de Rhizobium et Bradyrhizobium au niveau moleculaire et son utilisation en ecologie microbienne. Ph.D. Thesis, Université de Bourgogne.

HartmanN, A. \& Amarger, N. 1991 Genotypic diversity of an indigenous Rhizobium meliloti field population assessed by plasmid profiles, DNA fingerprinting and insertion sequence typing. Canadian Journal of Microbiology (in press).

KRZANowski, W.J. 1988 In Principles of Multivariate Analysis: A User's Perspective ed. Copas, J.B., Dawid, A.P., Eagleson, G.K., Pearce D.A. \& Silverman, B.W. pp. 369-400. Oxford: Oxford University Press.

MaCFIE, H.J.H. \& GuTteridge, C.S. 1982 Comparative studies on some methods for handling quantitative data generated by analytical pyrolysis. Journal of Analytical and Applied Pyrolysis 4, 175204.

MACFIE, H.J.H., GutTeridge, C.S. \& NoRris, J.R. 1978 Use of canonial variates analysis in differentation of bacteria by pyrolysis gas-liquid chromatography. Journal of General Microbiology 104, $67-74$.

Maniatis, T., Fritsch, E.F. \& Sambrook, J. 1982 Molecular Cloning: A Laboratory Manual. New York: Cold Spring Harbour Laboratory.

O'DONNEl, A.G., NorRIS, J.R., Berkeley, R.C.W., Claus, D., Kaneko, T., Logan, N.A. \& Nozaki, R. 1980 Characterization of Bacillus subtilis, pumilus, licheniformis and amyloliquefaciens by pyrolyis gasliquid chromotography, deoxyribonucleic aciddeoxyribonucleic acid hybridization, biochemical tests and API systems. International Journal of Systematic Bacteriology 30, 448-459.

Ruvkun, G.B., Long, S.R., Meade, H.M., van den Bos, R.C. \& Ausubel, F.M. 1982 A Rhizobium meliloti insertion sequence that transposes preferentially into nitrogen fixation genes. Journal of Molecular and Applied Genetics 1, 405-418.

Shute, L.A., GutTeridge, C.S., Norris, J.R. \& BerkeLEY, R.C.W. 1984 Curie-point pyrolysis mass spectrometry applied to characterization and identification of selected Bacillus species. Journal of General Microbiology 130, 343-355.

WhEATCROFT, R. \& WATSON, R.J. 1987 Identification and characterization of insertion sequence ISRml in Rhizobium meliloti JJ1c10. Canadian Journal of Microbiology 33, 314 321.

Windig, W., Haverkamp, J. \& Kistermaker, P.G. 1983 Interpretation of a set of pyrolysis mass spectra by discriminant analysis and graphical rotation. Analytical Chemistry 55, 387-391. 